\title{
Sprawozdanie z przebiegu uroczystości Jubileuszu 70. urodzin oraz 45. rocznicy pracy naukowej Profesora Zbigniewa Janku w dniu 27 października 2017 r.
}

Uroczyste obchody Jubileuszu urodzin oraz pracy naukowej dra hab. Zbigniewa Janku, prof. UAM rozpoczęły się o godzinie 12.00 w Collegium Minus, w Sali Lubrańskiego, zwanej Małą Aulą UAM, którą zdobi kopia obrazu Jana Matejki Założenie Akademii Lubrańskiego. Na tle tego obrazu za stołem prezydialnym zasiadł dziekan Wydziału Prawa i Administracji prof. zw. dr hab. Roman Budzinowski wraz z kierownikiem Katedry Prawa Administracyjnego i Nauki o Administracji prof. zw. drem hab. Markiem Szewczykiem. Dla Jubilata i Jego Małżonki, Jolanty Janku, przygotowano honorowe fotele.

W pierwszym rzędzie przeznaczonym dla gości miejsca zajęli przedstawiciele Prezydenta Miasta Poznania i Wojewody Wielkopolskiego, prodziekani Wydziału prawa i Administracji Uniwersytetu im. Adama Mickiewicza w Poznaniu oraz rodzina Jubilata. Pozostałą część publiczności stanowili zaproszeni goście, a także profesorowie, doktorzy habilitowani, doktorzy i magistrowie z poznańskiego ośrodka akademickiego oraz z innych uczelni w całym kraju.

Obchody Jubileuszu otworzył dziekan Wydziału Prawa i Administracji, który przypomniał wszystkim zebranym liczne zasługi Jubilata dla polskiej nauki, a także dla całego Uniwersytetu w Poznaniu. Dziekan pogratulował Profesorowi Zbigniewowi Janku niezłomnej postawy badacza w swojej dyscyplinie, ale i przykładnego pracownika naukowo-dydaktycznego, człowieka szanowanego i lubianego przez całą społeczność wydziałową oraz uczelnianą.

Następnie głos zabrał prof. zw. dr hab. Marek Szewczyk, który w imieniu Katedry Prawa Administracyjnego i Nauki o Administracji oraz własnym złożył gratulacje Jubilatowi. Mówca przypomniał lata sprawowania przez Profesora Janku funkcji kierownika Katedry Prawa Administracyjnego i Nauki o Administracji. Z prawdziwym sentymentem wspominał inicjatywy i działania Jubilata, pouczające dla kadry naukowej i rozwijające ją spotkania, wspólne wyjazdy na konferencje naukowe.

W dalszej kolejności wystąili profesorowie z Katedry Prawa Administracyjnego i Nauki o Administracji. Jako pierwszy głos zabrał dr hab. Krystian Ziemski, prof. UAM. W swym wystąpieniu skoncentrował się na osobie Jubilata jako swego wieloletniego przyjaciela. Nie stronił od barwnych opowieści z życia Profesora Janku, opisując zebranym gościom pasję Profesora związaną z miłością do gór i wędrówek 
górskimi szlakami w skupieniu i kontemplacji. Natomiast dr hab. Krystyna Wojtczak, prof. UAM w swoim wystąpieniu silnie zaakcentowała osiągnięcia Jubilata na tle wymagań w zakresie awansów naukowych pracowników nauki, w tym szczególnie tytułu profesora, przyjmowanych prawem na przestrzeni dziejów naszego państwa. Profesor Wojtczak bez wahania pozwoliła sobie na przyrównanie pozycji Jubilata do pozycji osób posiadających w niektórych państwach europejskich tytuł Full Professor, tj. tytuł najwyższy, wieńczący karierę naukową. Niewątpliwie, bogaty dorobek naukowy Profesora Janku pozwala na takie twierdzenie.

W tym miejscu Profesorowi Zbigniewowi Janku, w podziękowaniu za lata współpracy i rozwoju nauki prawa administracyjnego, wręczona została księga jubileuszowa pod tytułem $Z$ problematyki prawnej samorządu terytorialnego. Księge wręczył dziekan wraz z profesorami z Katedry Prawa Administracyjnego i Nauki o Administracji.

Kolejno głos zabrał uczeń i wychowanek Jubilata, dr hab. Bartosz Kołaczkowski. Prelegent przedstawił szeroko dorobek naukowy swojego Promotora. Uczeń Pana Profesora trafnie zwrócił uwagę, że Profesor nigdy nie bał się podejmować trudnych i wywołujących wiele sporów w doktrynie problemów. Swoją przygodę naukową rozpoczął od ambitnego tematu zagadnień ustrojowych, a mianowicie pozycji terenowych organów władzy państwowej, ówczesnych rad narodowych i naczelników miast najniższego stopnia. Profesor Janku, obserwując i analizując liczne przemiany polityczne i społeczne w naszym kraju, szczególną uwagę w swojej pracy naukowej skierował na materię samorządu terytorialnego. Ponadto w licznych publikacjach podejmował także badania w zakresie administracyjnego prawa materialnego, tj. prawa o zgromadzeniach, stowarzyszeniach, cudzoziemcach czy drogach publicznych.

Następnym prelegentem była dr Eliza Kania, przedstawiciel Prezydenta Miasta Poznania Jacka Jaśkowiaka, która podkreśliła wkład Jubilata w rozwój poznańskiej nauki, a także jego udział w promowaniu i doskonaleniu samorządności. Pan Profesor Zbigniew Janku otrzymał odznakę honorową miasta Poznania.

Następnie odczytane zostały adresowane do Jubilata listy gratulacyjne przekazane przez Jego Magnificencję Rektora UAM dra hab. Andrzeja Lesickiego, prof. UAM, a także przez Kanclerza UAM Stanisława Wachowiaka. Władze uniwersyteckie szczególnie podkreśliły znaczenie działalności Profesora Janku dla Wydziału Prawa i Administracji. Nie może umknąć uwadze fakt, że Profesor Zbigniew Janku w trakcie swojej kariery piastował m.in. funkcje: Prodziekana Wydziału Prawa i Administracji UAM w latach 2003-2008, Rzecznika Dyscyplinarnego UAM ds. nauczycieli akademickich w latach 2000-2002, Kierownika Podyplomowego Studium Administracji w latach 1991-1997, Przewodniczącego Komisji Rekrutacyjnej na kierunku prawo w latach 2003-2008, członka Komisji Rektorskiej ds. studiów zaocznych w latach 2002-2005 oraz od 1989 r. członka Rady Wydziału Prawa i Administracji.

Po uroczystych wystąieniach Chór Akademicki UAM pod batutą dyrygent Beaty Bielskiej wykonał trzy utwory. Uczta muzyczna wprawiła Jubilata i zebranych gości w pogodny nastrój, a także wpłynęła na swobodę wypowiedzi kolejnych prelegentów.

Po tej chwili przerwy, głos zabrał sam Jubilat, który w swym krótkim, ale treściwym i bardzo radosnym wystąpieniu podziękował za tak liczne przybycie gościom 
z innych polskich ośrodków uniwersyteckich, a także organizatorom za przygotowanie wzruszającej i podniosłej uroczystości dla niego i jego najbliższych.

Następnymi mówcami byli przyjaciele Jubilata, m.in. prof. Barbara Adamiak (kierownik Zakładu Postępowania Administracyjnego i Sądownictwa Administracyjnego Wydziału Prawa, Administracji i Ekonomii Uniwersytetu Wrocławskiego) przypominająca liczne wspólnie z Nim odbyte konferencje, a także prof. Barbara Jaworska-Dębska (kierownik Zakładu Prawa Samorządu Terytorialnego Wydziału Prawa i Administracji Uniwersytetu Łódzkiego), która mówiła o łączących ją z Jubilatem zainteresowaniach merytorycznych koncentrujących się na problematyce samorządu terytorialnego oraz o wielogodzinnych dyskusjach z Nim prowadzonych.

Na zakończenie młodsza kadra naukowo-dydaktyczna Katedry Prawa Administracyjnego i Nauki o Administracji wręczyła Jubilatowi kwiaty w podziękowaniu za wsparcie merytoryczne i organizacyjne Katedry i jej pracowników oraz doktorantów, życząc Mu dalszej owocnej pracy naukowej.

Po części oficjalnej Jubilat wraz z rodziną i gośćmi udał się na uroczysty obiad, kontynuując rozmowy naukowe i towarzyskie.

W czasie uroczystości dystrybuowana była wspomniana wcześniej księga jubileuszowa pod redakcją prof. Marka Szewczyka zatytułowana Z problematyki prawnej samorzadu terytorialnego. Publikacja została wydana dla uczczenia 70. rocznicy urodzin oraz 45. rocznicy pracy naukowej Profesora Zbigniewa Janku nakładem Wydawnictwa Naukowego UAM. Monografię tworzą teksty, których autorami są przyjaciele oraz współpracownicy Jubilata. Poszczególne rozdziały księgi dotyczą najistotniejszych i najbardziej aktualnych zagadnień mieszczących się w szeroko pojętej problematyce samorządu terytorialnego. Inspiracją dla wyboru tematyki były zainteresowania badawcze Jubilata, który poświęcił większość swego dorobku naukowego zagadnieniu samorządu terytorialnego, a także obchodzona w 2015 r. rocznica reaktywowania samorządu terytorialnego na szczeblu gminnym. Wśród autorów opracowań znaleźli się najwybitniejsi przedstawiciele nauki prawa i postępowania administracyjnego oraz nauki administracji.

Monografia, zamiast zwyczajowego wstępu, zawiera przedmowę dotyczącą postaci Jubilata napisaną przez redaktora naukowego prof. Marka Szewczyka. Z opisu dowiadujemy się, że Profesor Zbigniew Janku jako jeden z najwybitniejszych przedstawicieli polskiej nauki prawa administracyjnego jest także znanym i cenionym uczonym poza granicami Polski, a zwłaszcza w Republice Czeskiej. O pozycji Jubilata zdecydowało kilka czynników: aktywność na polu naukowym, zwłaszcza w zakresie badań naukowych, działalność w obszarze dydaktyki, m.in. w zakresie wychowania młodej kadry naukowej, oraz praca o charakterze organizacyjnym w dziedzinie nauki.

Aktywność Jubilata na polu naukowym najpełniej ujawniła się w Jego dorobku, na który składają się liczne monografie, komentarze, podręczniki akademickie, a także inne opracowania, takie jak artykuły czy referaty przygotowywane na konferencje naukowe, następnie wydawane w wieloautorskich monografiach pokonferencyjnych. Z pełnym wykazem publikacji, których Profesor Zbigniew Janku był autorem lub redaktorem naukowym, można zapoznać się, sięgając do księgi jubileuszowej (s. 7-14). Lista zawiera łącznie aż 109 pozycji. Opracowania dotyczą głównie ustrojowego oraz materialnego prawa administracyjnego, do ulubionych 
zaś obszarów zainteresowań i aktywności twórczej należy problematyka prawa ustrojowego samorządu terytorialnego.

Profesor Zbigniew Janku ma również niezaprzeczalne sukcesy w zakresie kształcenia młodej kadry naukowej. Spora grupa autorów księgi jubileuszowej to byli słuchacze wykładów czy seminarzyści Profesora. W wielu przypadkach Jubilat był też ich egzaminatorem oraz opiekunem prac magisterskich, a także doktorskich. Dorobek Profesora Janku w tym zakresie nie ogranicza się tylko do byłych studentów Uniwersytetu im. Adama Mickiewicza w Poznaniu. Profesor był chętnie zapraszany do pełnienia roli recenzenta w przewodach doktorskich i habilitacyjnych otwieranych na innych uczelniach. Sukcesy w tym zakresie niewątpliwie odnosił także dzięki swemu charakterowi i osobowości - pomimo stawiania niezwykle wysokich wymagań jednocześnie zawsze okazywał życzliwość swoim podopiecznym. Jubilat był i nadal jest wnikliwym uczestnikiem dyskusji naukowych prowadzonych podczas zebrań w Katedrze Prawa Administracyjnego i Nauki o Administracji. Niezwykle celne i wyważone uwagi Profesora przekazywane młodej kadrze naukowej są bezcenne.

W przedmowie dotyczącej Jubilata nie pozostały niezauważone osiągnięcia o charakterze organizacyjnym w dziedzinie nauki. Profesor Zbigniew Janku przez ponad szesnaście lat, aż do osiągnięcia wieku emerytalnego, pełnił z powodzeniem funkcję kierownika Katedry Prawa Administracyjnego i Nauki o Administracji. Ponadto, poza wieloma wcześniej wymienionymi funkcjami pełnionymi $\mathrm{w}$ ramach struktur uniwersyteckich, Profesor był członkiem licznych stowarzyszeń (m.in. Poznańskiego Towarzystwa Przyjaciół Nauk i Stowarzyszenia Edukacji Administracji Publicznej), a także redakcji oraz rad naukowych czasopism naukowych. Należy nadmienić, że Jubilat pełnił również ważne funkcje poza strukturami UAM, m.in. w latach 1998-2002 był rektorem Wyższej Szkoły Zarządzania i Bankowości w Poznaniu. Na uczelni tej Profesor prowadził także wykłady i seminaria z prawa administracyjnego.

W księdze jubileuszowej dedykowanej niezwykłej osobie Profesora znalazły się 23 artykuły poświęcone szeroko rozumianej problematyce samorządu terytorialnego. Wystarczy w tym miejscu wskazać na opracowania profesorskie, wśród których znalazły się teksty: prof. zw. dr hab. Barbary Adamiak Utrata kompetencji przez organ samorządu terytorialnego sankcja za naruszanie zasady praworządności, prof. zw. dra hab. Bogdana Dolnickiego Tworzenie jednostek pomocniczych gminy, prof. zw. dr hab. Bożeny Popowskiej Zadania gmin w zakresie gminnych przewozów pasażerskich. Instrumenty wdrażania konkurencji regulowanej, prof. zw. dra hab. Jerzego Supernata Samorzad terytorialny w Irlandii czy prof. zw. dr hab. Elżbiety Ury i prof. zw. dra hab. Stanisława Pieprznego Płaszczyzny zadań wykonywanych przez starostę. Nie zabrakło również opracowań przygotowanych przez współpracowników Jubilata - profesorów z Katedry Prawa Administracyjnego i Nauki o Administracji: prof. zw. dra hab. Marka Szewczyka (Referendum lokalne jako jeden ze sposobów oraz forma wykonywania przez jednostki samorzadu terytorialnego ich zadań) oraz dra hab. Krystiana Ziemskiego, prof. UAM, który napisał artykuł wspólnie z mgrem Maciejem Kiełbusem (Wybrane zagadnienia stanowienia aktów prawa miejscowego przez organy publicznoprawnych związków jednostek samorządu terytorialnego).

Wymienione tematy opracowań stanowią jedynie przykład obrazujący, jak rozległa jest tematyka prawa samorządu terytorialnego, którą zają się w swojej 
pracy naukowej Profesor Zbigniew Janku. Potwierdza to również objętość księgi jubileuszowej, która liczy aż 338 stron.

Uroczystość jubileuszowa była okazją do spotkań, wielu wspomnień i uśmiechu. Wszystkim uczestnikom tego wydarzenia serdecznie dziękujemy.

Lucyna Staniszewska, Maria Jędrzejczak DOI: $10.14746 /$ spp.2017.4.20.13 